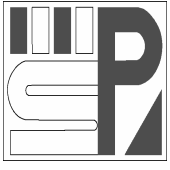

Science Press

Journal of Arid Land

2012, 4(4): 431-440

doi: 10.3724/SP.J.1227.2012.00431

jal.xjegi.com; www.chinasciencejournal.com

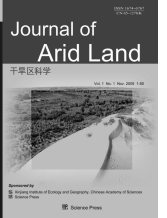

\title{
The return and loss of litter phosphorus in different types of sand dunes in Horqin Sandy Land, northeastern China
}

\author{
QuanLai ZHOU*, DeMing JIANG, ZhiMin LIU, Alamusa, XueHua LI, YongMing LUO, HongMei WANG \\ Institute of Applied Ecology, Chinese Academy of Sciences, Shenyang 110016, China
}

\begin{abstract}
Litter phosphorus $(\mathrm{P})$ return is important to maintain the $\mathrm{P}$ cycle and balance in the sandy land of arid areas. In this study, we determined the loss and return of litter $\mathrm{P}$ in sand dune areas and elucidated their relationship. We investigated litter production and litter $\mathrm{P}$ amount, and simulated leaf litter moving dynamics to understand the relationships between the loss of litter $P$ and the total litter $P$, and between the return of litter $P$ and the total litter $P$ in active (AD), semi-stabilized (SSD) and stabilized (SD) dunes in Inner Mongolia, northeastern China. The vegetation litter $P$ was 12.6, 94.5, and $201.6 \mathrm{mg} \mathrm{P} / \mathrm{m}^{2}$ in AD, SSD, and SD, respectively. A significant movement and loss of leaf litter $P$ with time occurred on the three types of sand dunes. As a result, the loss of $P$ was $7.4,46.9$, and $69.8 \mathrm{mg} \mathrm{P} / \mathrm{m}^{2}$ and the return of $P$ was $5.5,47.6$, and $131.8 \mathrm{mg} \mathrm{P} / \mathrm{m}^{2}$ in $\mathrm{AD}, \mathrm{SSD}$, and SD, respectively. The relationship between both loss and return of $P$ and total litter $P$ in $A D, S S D$, and SD was revealed by linear regression. The slope of the regression line indicated the rate of loss or return of litter P. From AD to SD, the loss rate showed a declining slope $(0.52,0.32$, and 0.17 for $A D, S S D$, and $S D$, respectively), and the return rate showed a rising slope $(0.48,0.67$, and 0.83 for $A D, S S D$, and SD, respectively). The loss of litter $P$ should be regarded in the local management of vegetation and land in sand dune areas. Improved vegetation restoration measures are necessary to decrease litter $P$ loss to maintain the stability of ecosystems in sand dune areas.
\end{abstract}

Keywords: leaf litter; litter loss; litter production; sand dune areas; vegetation restoration

Phosphorus $(\mathrm{P})$ is an important plant nutrient in terrestrial ecosystem productivity because the soil $\mathrm{P}$ reservoir derived from soil parent materials and atmospheric sources is limited (Cole et al., 1977; Okin et al., 2004; Filippelli, 2008). Thus, a balance between the return and loss of soil $\mathrm{P}$ is a key to preserving the soil $\mathrm{P}$ reservoir (Filippelli, 2008). However, the soil P reservoir exists at low levels in sandy soils in arid areas (Chen et al., 2003; Zhao et al., 2008). The mobility and availability of $\mathrm{P}$ are also largely restrained in such areas because phosphate ions in soils are sensitive to soil moisture, thus limiting vegetation productivity in the sandy soils (He et al., 2002; Smith, 2002). A continuous $\mathrm{P}$ cycle and $\mathrm{P}$ balance in arid areas is necessary to maintain the soil $\mathrm{P}$ reservoir and ecosystem productivity.
Vegetation litter is important for the material cycle of terrestrial ecosystems (Berg and McClaugherty, 1989). The process of litter decomposition, nutrient release, and soil organic matter formation is important in the P cycle of an ecosystem (Berg, 2000; Osono and Takeda, 2004). With litter decomposition, soil nutrition reserves are renewed and reused by vegetation (Berg and McClaugherty, 1989; Moretto et al., 2001; Martinez-Yrizar et al., 2007). Therefore, the return of litter is an important factor in sustaining $\mathrm{P}$ cycle and soil $\mathrm{P}$ balance in the ecosystem.

Many researchers have studied the litter nutrient return of trees in forestry (Costa et al., 2004; Meier et al., 2005), plantation (Njoukam et al., 1999; Yang et

Received 2012-01-13; accepted 2012-05-11

*Corresponding author: QuanLai ZHOU (E-mail: zhouquanlai@126.com) 
al., 2004), agroforestry (Silveira et al., 2007; Jaramillo-Botero et al., 2008), and desert (Kemp et al., 2003) systems. These studies mainly focused on nutrient reuse and turnover rate. However, severe land degradation has decreased the biomass of vegetation on the surface of sandy land systems (Zuo et al., 2008; Li et al., 2009) and vegetation cannot effectively reduce wind speed on the soil surface, leading to leaf litter loss $(\mathrm{Hu}$ et al., 2009). Little information is available on the litter loss and litter P return in sandy land.

The Horqin Sandy Land has a continental semi-arid monsoon climate. The landscape is characterized by a mosaic of stabilized (SD), semi-stabilized (SSD), and active (AD) dunes, including dune slacks (Liu et al., 2008). According to data from the Wulanaodu meteorological station, the annual average wind speed in the area is $4.4 \mathrm{~m} / \mathrm{s}$ with frequent gales during the windy season from March to May (Yan et al., 2005). The daily maximum wind speed at $0.25-\mathrm{m}$ elevation in Naiman county in the south-central part of the Horqin Sandy Land is $13.1,10.1$, and $7.2 \mathrm{~m} / \mathrm{s}$ in AD, SSD, and SD, respectively (Li et al., 2005). The vegetation cover is significantly different across different sand dune types, being $<5 \%, 5 \%$ to $50 \%$, and $>50 \%$ in $\mathrm{AD}$, $\mathrm{SSD}$, and SD, respectively. As variations in vegetation cover result in different wind-breaking abilities (Hu et al., 2009), varied vegetation cover and strong aeolian activities bring about different litter loss rates among the three types of sand dunes.

In this study, we investigated litter production in the three types of sand dunes, determined litter P concentration, and simulated the dynamics of litter loss. The objectives of the experiment are to clarify (1) the amount of litter $\mathrm{P}$ in different types of sand dunes, (2) the amount of $\mathrm{P}$ returned and lost in different types of sand dunes, and (3) the relationships between both return and loss of $\mathrm{P}$ and total litter $\mathrm{P}$.

\section{Materials and methods}

\subsection{Study area}

The study area is located at the west of the Horqin Sandy Land in Wulanaodu village $\left(43^{\circ} 03^{\prime} \mathrm{N}, 119^{\circ} 39^{\prime} \mathrm{E}\right.$; $480 \mathrm{~m}$ asl), Wengniute county, Inner Mongolia, China (Fig. 1). The Wulanaodu region has windy and dry winters and springs and warm and rather rain-rich summers followed by a short and cool fall. The annual mean temperature is $6.2^{\circ} \mathrm{C}$, and the mean annual precipitation is $340 \mathrm{~mm}$, about $70 \%$ of which occurs between June and September. The annual potential evaporation is $2,300 \mathrm{~mm}$, about six times the annual precipitation. The growing season lasts $140 \mathrm{~d}$ from April to September.

We conducted the experiment on $\mathrm{AD}, \mathrm{SSD}$, and SD. The $\mathrm{AD}$ site $\left(43^{\circ} 00^{\prime} \mathrm{N}, 119^{\circ} 37^{\prime} \mathrm{E}\right)$ was situated at an elevation of $15 \mathrm{~m}$ to $20 \mathrm{~m}$ and showed the strongest wind erosion on the windward slope and sand burial on the leeward slope from March to May. Sand erosion and accumulation on the top of AD was significant because of sand movement. The mean advancing rate of sand dunes was 1.5 to $3.0 \mathrm{~m} / \mathrm{a}$. Large chains of sand dunes were formed by prevailing winds. The vegetation, distributed on the top and the leeward slope of the sand dunes, was highly fragmented with large bare areas covering $1 \%$ to $2 \%$ of the land. Some pioneering plants, including Salix gordejevii, Artemisa wudanica, Agriophyllum arenarium, and Corispermum thelegium, were oberseved in the area. The SSD site $\left(43^{\circ} 02^{\prime} \mathrm{N}, 119^{\circ} 40^{\prime} \mathrm{E}\right)$ was located at an elevation of $3 \mathrm{~m}$ to $5 \mathrm{~m}$ with a gradual slope and had a weak wind erosion and sand accumulation during the windy season. Large soil particles characterized the surface because fine soil was eroded away by wind. The dominant species was Caragana microphylla, which grew sparsely in the area (mean distance 4.5 to $5.0 \mathrm{~m}$, height 70 to $150 \mathrm{~cm}$ ). Other species included the semi-shrub Artemisia ordosica (more sparsely distributed, 50 to $80 \mathrm{~cm}$ in height) and herbs Bassia dasyphylla, C. thelegium, Cynanchum thesioides, and Tribulus terrestris $(<50 \mathrm{~cm}$ in height). The vegetation cover was about $30 \%$. The SD site $\left(43^{\circ} 03^{\prime} \mathrm{N}\right.$, $119^{\circ} 39^{\prime} \mathrm{E}$ ), which was previously SSD and had been fenced off since 2004, had a vegetation cover of over $50 \%$. The dominant species here were C. microphylla and $A$. ordosica. Plant distribution pattern and height of the two species were similar to those in SSD. Other species included Chenopodium acuminatum, Setaria viridis, Digitaria sanguinalis, Diarthron linifolium, and Aristida adscensionis (20 to $80 \mathrm{~cm}$ in height).

Herbs in the study sites were mainly annual plants. Stems of dead plants but few dried leaves were found 
on the surfaces of all three sand dune types. The dead stems were mainly plant residuals of $B$. dasyphylla, $D$. linifolium, A. arenarium, $C$. thelegium, $C$. acuminatum, and so on. AD and SSD showed weak wind-breaking effects because of the sparse distribution of herb stems, whereas SD showed greater effectiveness because of larger vegetation cover. Soils were sandy, loose in structure, and prone to wind erosion in all three sand dune types. Some soil chemical properties are shown in Table 1.

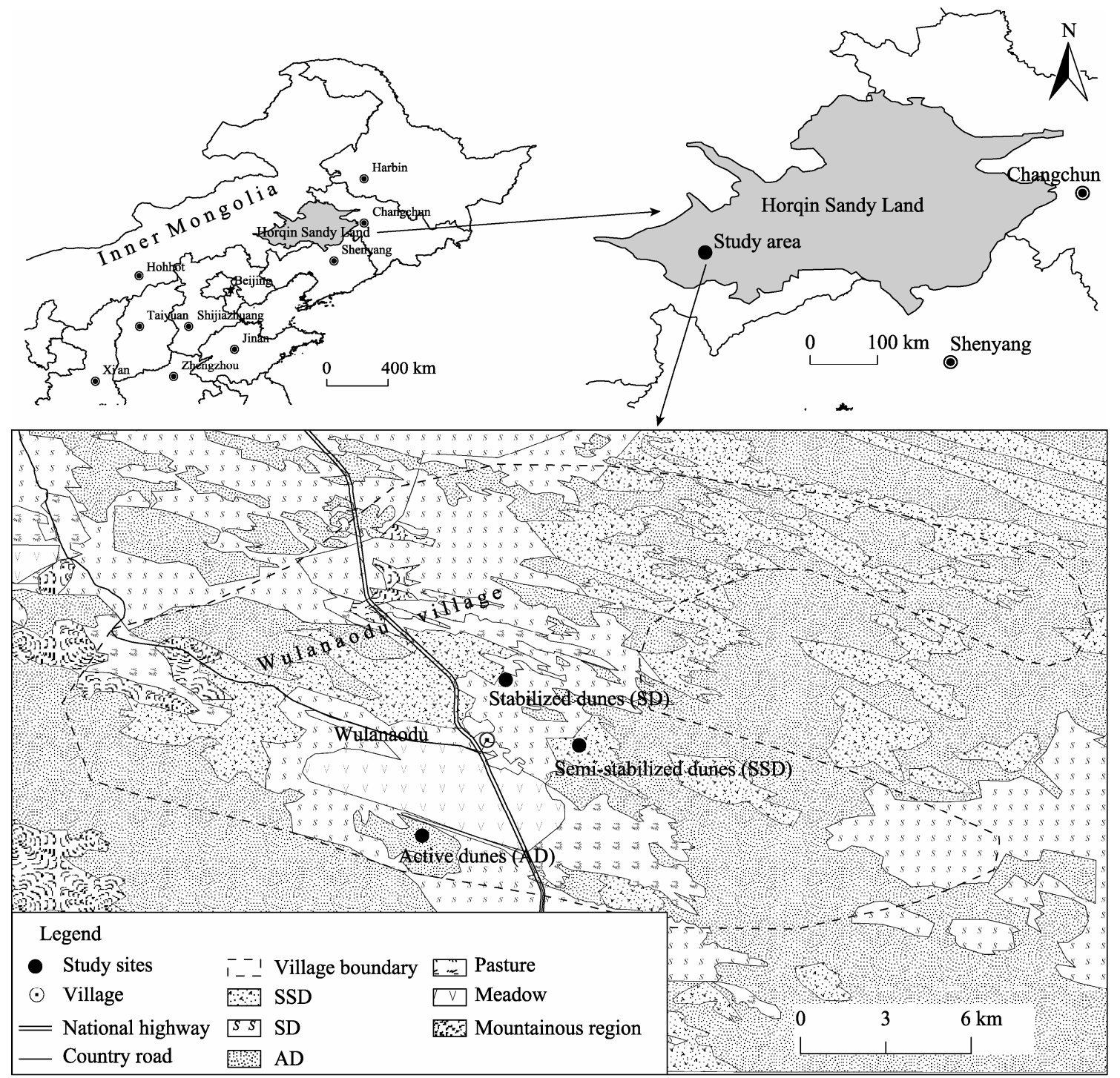

Fig. 1 Location of the study area in Horqin Sandy Land and the study sites for three sand dune types, i.e. AD, SSD, and SD

Table 1 Chemical properties of soils in the three types of sand dunes

\begin{tabular}{cccccccc}
\hline $\begin{array}{c}\text { Depth } \\
(\mathrm{cm})\end{array}$ & $\begin{array}{c}\text { Soil } \\
\text { type }\end{array}$ & $\begin{array}{c}\text { Total N } \\
(\mathrm{g} / \mathrm{kg})\end{array}$ & $\begin{array}{c}\text { Total P } \\
(\mathrm{g} / \mathrm{kg})\end{array}$ & $\begin{array}{c}\text { Total K } \\
(\%)\end{array}$ & $\begin{array}{c}\text { Available P } \\
(\mathrm{mg} / \mathrm{kg})\end{array}$ & $\begin{array}{c}\text { Organic C } \\
(\mathrm{g} / \mathrm{kg})\end{array}$ \\
\hline $0-10$ & $\mathrm{AD}$ & $0.04 \pm 0.01^{\mathrm{c}}$ & $0.12 \pm 0.02^{\mathrm{b}}$ & $2.81 \pm 0.14^{\mathrm{a}}$ & $2.19 \pm 0.48^{\mathrm{b}}$ & $7.83 \pm 0.16^{\mathrm{a}}$ & $0.06 \pm 0.01^{\mathrm{c}}$ \\
& $\mathrm{SSD}$ & $0.17 \pm 0.06^{\mathrm{b}}$ & $0.14 \pm 0.03^{\mathrm{ab}}$ & $2.51 \pm 0.23^{\mathrm{b}}$ & $2.95 \pm 0.43^{\mathrm{b}}$ & $6.89 \pm 0.27^{\mathrm{b}}$ & $0.65 \pm 0.12^{\mathrm{b}}$ \\
& $\mathrm{SD}$ & $0.30 \pm 0.06^{\mathrm{a}}$ & $0.19 \pm 0.04^{\mathrm{a}}$ & $2.85 \pm 0.21^{\mathrm{a}}$ & $5.47 \pm 2.53^{\mathrm{a}}$ & $6.88 \pm 0.09^{\mathrm{b}}$ & $1.28 \pm 0.11^{\mathrm{a}}$ \\
$10-20$ & $\mathrm{AD}$ & $0.03 \pm 0.00^{\mathrm{b}}$ & $0.12 \pm 0.01^{\mathrm{b}}$ & $2.77 \pm 0.05^{\mathrm{ab}}$ & $2.56 \pm 0.60^{\mathrm{a}}$ & $7.74 \pm 0.17^{\mathrm{a}}$ & $0.05 \pm 0.01^{\mathrm{c}}$ \\
& $\mathrm{SSD}$ & $0.15 \pm 0.05^{\mathrm{a}}$ & $0.14 \pm 0.02^{\mathrm{ab}}$ & $2.60 \pm 0.24^{\mathrm{b}}$ & $1.01 \pm 0.62^{\mathrm{b}}$ & $6.72 \pm 0.21^{\mathrm{b}}$ & $0.49 \pm 0.02^{\mathrm{b}}$ \\
& $\mathrm{SD}$ & $0.16 \pm 0.06^{\mathrm{a}}$ & $0.15 \pm 0.02^{\mathrm{a}}$ & $2.96 \pm 0.13^{\mathrm{a}}$ & $1.83 \pm 0.73^{\mathrm{ab}}$ & $6.89 \pm 0.10^{\mathrm{b}}$ & $1.05 \pm 0.08^{\mathrm{a}}$ \\
\hline
\end{tabular}


We selected three sand dunes for each sand dune type and one plot $(50 \mathrm{~m} \times 50 \mathrm{~m})$ on the top of each sand dune. That is, in total, three plots, as replicates, were set up for each sand dune type.

\subsection{Litter production of shrubs and semi-shrubs}

Shrub and semi-shrub litter including wilted flowers, fruits and leaves was collected from each study plot using 5 square litter traps $(0.5 \mathrm{~m} \times 0.5 \mathrm{~m} \times 0.1 \mathrm{~m}$, made of $1 \mathrm{~mm}$ nylon net) from April to October 2008. We emptied the traps once a month. We investigated shrub and semi-shrub cover in quadrats $(4 \mathrm{~m} \times 4 \mathrm{~m})$ by drawing projected areas on graphing paper to evaluate cover accurately. According to the coverage and litter biomass in the traps, the average litter production of shrubs and semi-shrubs in a quadrat could be calculated as follows:

$$
P=S \times C .
$$

Where $P$ is the litter production under shrub or semi-shrub canopy $\left(\mathrm{g} / \mathrm{m}^{2}\right) ; S$ is the shrub or semi-shrub litter biomass in the trap $\left(\mathrm{g} / \mathrm{m}^{2}\right)$; and $C$ is the shrub and semi-shrub cover (\%).

Litter samples from each trap were oven dried at $80^{\circ} \mathrm{C}$ for $24 \mathrm{~h}$, milled $(<0.15 \mathrm{~mm})$, mixed, and stored for analysis.

\subsection{Litter production of herbs}

Herb leaves and stems were treated as litter, because they decompose after the growing season and, thus, enter the material cycle. Winds blow away the leaves and herb stems remain during the windy season. Therefore, we investigated the biomass of leaves and stems of herbs separately.

Twenty random quadrats $(1 \mathrm{~m} \times 1 \mathrm{~m})$ were investigated in each spot, a total of 60 quadrats for each sand dune type. The leaves and stems of each species in every quadrat were gathered respectively, oven dried (at $80^{\circ} \mathrm{C}$ for $24 \mathrm{~h}$ ) and weighted. Five replicates of the stem and leaf samples of each species were taken, dried, and milled $(<0.15 \mathrm{~mm})$ respectively, and stored for analysis.

All samples were analyzed for total P (TP) concentration by colorimetric analysis following the Kjeldahl digestion method (Bremner, 1996). The amount of $P$ in leaves and stems was calculated according to the $\mathrm{P}$ concentration and biomass in the study sites.

\subsection{Leaf litter movement simulation}

We conducted a simulation experiment on litter movement by wind power in three plots to determine the leaf loss amount. We placed 200 pieces of small, circular paper ( $8 \mathrm{~mm}$ in diameter) to simulate leaves in a little circle (50 $\mathrm{cm}$ in radius) in the middle of each spot on $1^{\text {st }}$ October 2008. The origin was set at the centre of the circle. The direction of the prevailing wind was regarded as the positive Y-axis, and the line perpendicular to the Y-axis through the origin was the $\mathrm{X}$-axis (Fig. 2). The coordinates of the repositioned pieces of paper were measured along the $x$ and $y$ axes using a meter stick. We surveyed the locations of the paper pieces and recorded the coordinates $P\left(x_{i}, y_{i}\right)$ every 2 months until $1^{\text {st }}$ April 2009.

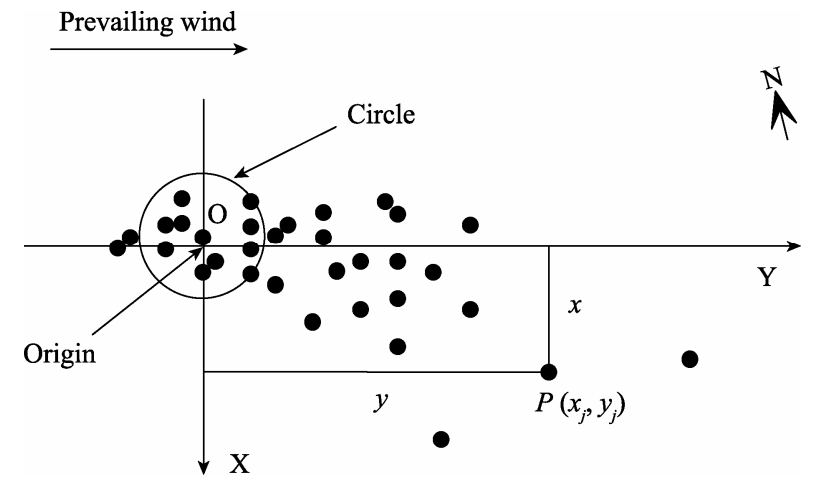

Fig. 2 Method of determining the location of paper in simulated leaf litter moving dynamics. Point $O$ is the origin of the intersection of the $\mathrm{X}$-axis and $\mathrm{Y}$-axis. Point $P\left(x_{i}, y_{i}\right)$ represents the coordinates of paper. The distance is $x$ from the $Y$-axis to the point and $y$ from the $X$-axis to the point. We determined the coordinates of the point by measuring $x$ and $y$ using a meter stick.

We assumed that the $\mathrm{P}$ in the litter not blown away was returned to soil through decomposition. The litter $P$ balance can then be calculated as:

$$
P_{\text {Return }}=P_{\text {Total }}-P_{\text {Loss }} \text {. }
$$

Where $P_{\text {Return }}$ is the P returned to soil from litter through decomposition; $P_{\text {Total }}$ is the $\mathrm{P}$ in total plant litter on the sand dunes from different sites; and $P_{\text {Loss }}$ is the $\mathrm{P}$ in the litter blown away by wind.

\subsection{Data analysis}

One-way ANOVA was carried out to test the significance of treatment effects on litter biomass and the amounts of $\mathrm{P}$ in shrub, semi-shrub, and herbaceous 
leaves and stems. Means were compared using Duncan's least significant ranges (LSRs) when the treatment effects were significant. Regression analysis was used to generate the regression coefficient between the loss and return of $\mathrm{P}$ in the three types of sand dunes. All statistical analyses were determined using SPSS 12.0.

The distribution of the pieces of paper was drawn using the mapping software ArcGIS v. 9.0. Histograms of the number of paper pieces distributed at various distances and the graph of the regression relationship between the loss and return of $\mathrm{P}$ in the three types of sand dunes were plotted using SigmaPlot v. 9.0.

\section{Results}

\subsection{Amount of $P$ in shrubs and semi-shrubs litter from different types of sand dunes}

Litter biomass and amount of $\mathrm{P}$ in shrubs were significantly higher than in semi-shrubs in SD and SSD $(P<0.01$, Table 2$)$. However, no significant differences in the litter biomass and amount of $P$ between shrubs and semi-shrubs were found in $\mathrm{AD}(P>0.05$,
Table 2). The litter biomass and amount of $\mathrm{P}$ in shrubs and semi-shrubs were significantly different $(P<0.05$, Table 2$)$ among SD, SSD, and AD. The sum of litter biomass and amount of $\mathrm{P}$ in shrubs and semi-shrubs were significantly different among the three study sites $(P<0.01$, Table 2$)$. The sum of shrub litter biomass in SD was the highest (1.2 times and 25.7 times those in SSD and $\mathrm{AD}$, respectively) among the three types of sand dunes. The total amount of litter P in shrubs in SD was 1.2 and 20.5 times those in SSD and $\mathrm{AD}$, respectively.

\subsection{Contribution of herbs to the amount of litter $P$}

The litter biomass of herbaceous stems was 2.1 and 2.0 times those of leaves in SSD and SD, respectively $(P<0.01$, Table 3$)$. However, the total biomasses of both stems and leaves were not significantly different in $\mathrm{AD}(P>0.05$, Table 3$)$. The biomasses of leaves, stems, and their sum in SD were significantly higher than those in SSD and $\mathrm{AD}(P<0.01$, Table 3$)$. However, individual differences in SSD and AD were not significant $(P>0.05$, Table 3$)$. The sum of leaf and stem biomasses in SD was 3.1 and 11.7 times those in SSD and $\mathrm{AD}$, respectively.

Table 2 Litter biomass and the amount of $P$ in shrub and semi-shrub litter in the three types of sand dunes

\begin{tabular}{lccccc}
\hline & Life form & AD & SSD & SD & $P$ value \\
\hline Average litter biomass $\left(\mathrm{g} / \mathrm{m}^{2}\right)$ & Shrub & $0.8 \pm 3.6^{\mathrm{b}}$ & $26.6 \pm 13.4^{\mathrm{a}^{*}}$ & $28.9 \pm 16.7^{\mathrm{a}^{*}}$ & $<0.001$ \\
& Semi-shrub & $0.6 \pm 2.2^{\mathrm{b}}$ & $3.2 \pm 5.4^{\mathrm{b}}$ & $7.1 \pm 7.9^{\mathrm{a}}$ & 0.010 \\
$P$ value & & 0.539 & 0.000 & 0.000 & $<.0001$ \\
Total biomass in three sites $\left(\mathrm{g} / \mathrm{m}^{2}\right)$ & & $1.4 \pm 4.1^{\mathrm{b}}$ & $29.8 \pm 16.1^{\mathrm{b}}$ & $36.0 \pm 19.8^{\mathrm{a}}$ & $<0.001$ \\
& Shrub & $1.1 \pm 4.1^{\mathrm{b}}$ & $35.0 \pm 17.9^{\mathrm{a}^{*}}$ & $38.0 \pm 22.4^{\mathrm{a}^{*}}$ & $<0.001$ \\
Litter P amount $\left(\mathrm{mg} \mathrm{P} / \mathrm{m}^{2}\right)$ & Semi-shrub & $1.3 \pm 4.3^{\mathrm{b}}$ & $4.2 \pm 5.1^{\mathrm{ab}}$ & $9.3 \pm 7.3^{\mathrm{a}}$ & 0.040 \\
$P$ value & & 0.682 & 0.000 & 0.000 & $47.3 \pm 24.9^{\mathrm{a}}$ \\
Total P amount in three sites $\left(\mathrm{mg} \mathrm{P} / \mathrm{m}^{2}\right)$ & & $2.4 \pm 6.2^{\mathrm{b}}$ & $39.2 \pm 20.2^{\mathrm{a}}$ & $<0.001$ \\
\hline
\end{tabular}

Note: Means for different sand dunes in rows with the same letters are not significantly different. Within the same sand dune type in columns, ${ }^{*}$ represents significant difference between different plant life forms $(n=15)$.

Table 3 Herbaceous litter biomass and the amount of $P$ in leaves and stems in three types of sand dunes

\begin{tabular}{lccccc}
\hline & Parts & AD & SSD & SD & $P$ value \\
\hline Litter biomass $\left(\mathrm{g} / \mathrm{m}^{2}\right)$ & Leaf & $5.1 \pm 9.3^{\mathrm{b}}$ & $15.8 \pm 7.2^{\mathrm{b}}$ & $50.0 \pm 34.2^{\mathrm{a}}$ & $<0.001$ \\
& Stem & $7.8 \pm 14.3^{\mathrm{b}}$ & $32.6 \pm 13.0^{\mathrm{b}^{\mathrm{b}}}$ & $100.5 \pm 73.4^{\mathrm{a}^{*}}$ & $<0.001$ \\
$P$ value & & 0.487 & $<0.001$ & 0.008 & \\
Total litter biomass $\left(\mathrm{g} / \mathrm{m}^{2}\right)$ & & $12.9 \pm 23.6^{\mathrm{b}}$ & $48.4 \pm 19.5^{\mathrm{b}}$ & $150.5 \pm 102.0^{\mathrm{a}}$ & $<0.001$ \\
& Leaf & $4.8 \pm 8.7^{\mathrm{b}}$ & $23.0 \pm 15.4^{\mathrm{b}}$ & $61.2 \pm 53.6^{\mathrm{a}}$ & $<0.001$ \\
Litter P amount $\left(\mathrm{mg} \mathrm{P} / \mathrm{m}^{2}\right)$ & Stem & $5.5 \pm 10.1^{\mathrm{b}}$ & $32.3 \pm 14.7^{\mathrm{b}}$ & $93.1 \pm 75.7^{\mathrm{a}}$ & $<0.001$ \\
$P$ value & & 0.798 & 0.057 & 0.132 & $<0.001$ \\
Total litter P amount $\left(\mathrm{mg} \mathrm{P} / \mathrm{m}^{2}\right)$ & & $10.3 \pm 18.8^{\mathrm{b}}$ & $55.3 \pm 29.6^{\mathrm{b}}$ & $154.3 \pm 124.1^{\mathrm{a}}$ & $<0.001$ \\
\hline
\end{tabular}

Note: Different letters in a row indicate significant difference by LSR multiple test $(P<0.05)$. Within the same sand dune type in a column, ${ }^{*}$ represents significant difference between amounts of $\mathrm{P}$ in different plant parts $(n=60)$. 
The amount of litter $\mathrm{P}$ in stems was not significantly higher than those in leaves in $\mathrm{AD}, \mathrm{SSD}$, and $\mathrm{SD}$ $(P>0.05$, Table 3$)$. The amount of $\mathrm{P}$ in leaves, stems, and their sum in SD were significantly higher than those in SSD and $\mathrm{AD}(P<0.01$, Table 3$)$. However, no significant difference was found between SSD and AD $(P>0.05$, Table 3$)$. The total amount of leaves and stems $\mathrm{P}$ in SD was 2.8 and 15.0 times those in SSD and $\mathrm{AD}$, respectively.

Total litter biomass and litter $\mathrm{P}$ amount were significantly different among the three types of sand dunes $(P<0.001$, Table 4$)$. Among the three types of sand dunes, the litter biomass production and amount of $\mathrm{P}$ in $\mathrm{SD}$ were the highest while those in $\mathrm{AD}$ were the lowest.

Table 4 Total litter biomass and amount of $P$ in the three types of sand dunes

\begin{tabular}{ccc}
\hline & $\begin{array}{c}\text { Total litter biomass } \\
\left(\mathrm{g} / \mathrm{m}^{2}\right)\end{array}$ & $\begin{array}{c}\text { Litter P amount } \\
\left(\mathrm{mg} \mathrm{P} / \mathrm{m}^{2}\right)\end{array}$ \\
\hline AD & $14.4 \pm 24.7^{\mathrm{c}}$ & $12.6 \pm 20.6^{\mathrm{c}}$ \\
$\mathrm{SSD}$ & $78.3 \pm 16.9^{\mathrm{b}}$ & $94.5 \pm 27.1^{\mathrm{b}}$ \\
$\mathrm{SD}$ & $186.5 \pm 60.5^{\mathrm{a}}$ & $201.6 \pm 72.6^{\mathrm{a}}$ \\
$P$ value & $<0.001$ & $<0.001$ \\
\hline
\end{tabular}

Note: Means with the same letters are not significantly different $(n=60)$.

\subsection{Leaf litter movement simulation}

As shown in Fig. 3, no paper was found at the three $\mathrm{AD}$ plots during the first investigation. However, we found many paper pieces at the SD and SSD plots distributed within 0 to $12 \mathrm{~m}$ from the original location. Beyond $12 \mathrm{~m}$, paper pieces were sporadically found at the SSD and SD plots.

The percentages of the paper pieces recovered from the three sites were $84 \%, 40.5 \%$, and $24 \%$ of the total paper pieces for SSD and $81 \%, 47 \%$, and $36 \%$ of the total paper pieces for SD after $60 \mathrm{~d}, 120 \mathrm{~d}$, and $180 \mathrm{~d}$, respectively. Therefore, the average number of paper pieces found left at the SSD and SD plots significantly decreased over time $(P<0.01$, Fig. 4$)$.

The average number of the paper pieces recovered significantly decreased with the increase in moving distance. Within 0 to $2 \mathrm{~m}$ from the origin, the pieces of paper retrieved at the SSD plot after $60 \mathrm{~d}, 120 \mathrm{~d}$, and $180 \mathrm{~d}$ were 147,42 , and 20 , respectively (about $88 \%$, $52 \%$, and $41 \%$, respectively, of the total). However, the numbers of paper pieces found within the 2 to 12 $\mathrm{m}$ range after $60 \mathrm{~d}, 120 \mathrm{~d}$, and $180 \mathrm{~d}$ (Fig. 4) were 20,

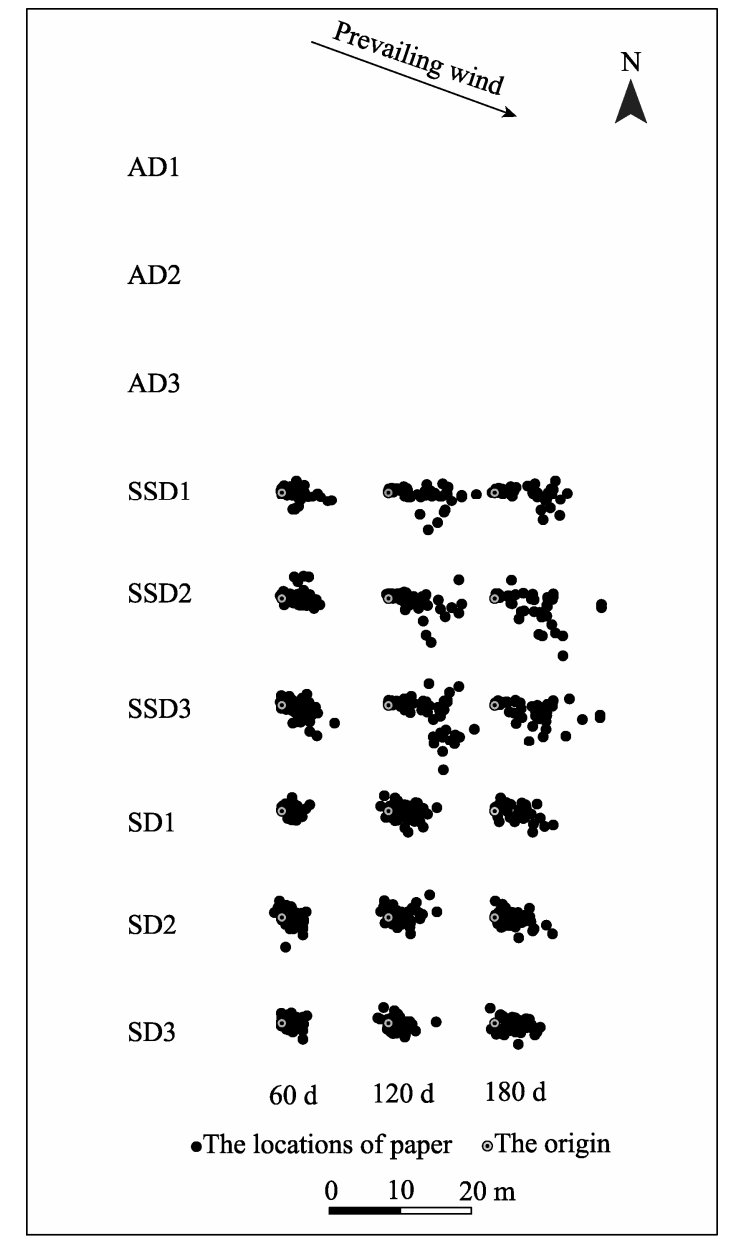

Fig. 3 The distribution of paper pieces after $60 \mathrm{~d}, 120 \mathrm{~d}$, and $180 \mathrm{~d}$ at $\mathrm{AD}, \mathrm{SSD}$, and SD plots

39 , and 29 , respectively, equivalent to $11 \%, 48 \%$, and $49 \%$ of the total. At the SD plot, the numbers of the pieces of paper retrieved within 0 to $2 \mathrm{~m}$ from the origin after $60 \mathrm{~d}, 120 \mathrm{~d}$, and $180 \mathrm{~d}$ were 152, 75, and 34, respectively (about $94 \%, 78 \%$, and $48 \%$, respectively, of the total). Within the 2 to $12 \mathrm{~m}$ range, on the other hand, the numbers of the pieces of paper retrieved after $60 \mathrm{~d}, 120 \mathrm{~d}$, and $180 \mathrm{~d}$ were 10,20 , and 37, respectively (about $6 \%, 22 \%$, and $52 \%$, respectively, of the total) (Fig. 4).

According to the leaf-litter dynamics experiment, the losses of leaf biomass by wind for AD, SSD, and SD were $6.6,34.5$, and $55.3 \mathrm{~g} / \mathrm{m}^{2}$, respectively (about $100 \%, 76 \%$, and $64 \%$ of the total leaf biomass, respectively). The litter-biomass return rates for $\mathrm{AD}$, $\mathrm{SSD}$, and SD were $7.8,43.8$, and $131.2 \mathrm{~g} / \mathrm{m}^{2}$, equivalent to $54.2 \%, 55.9 \%$, and $70.3 \%$, respectively, of the 


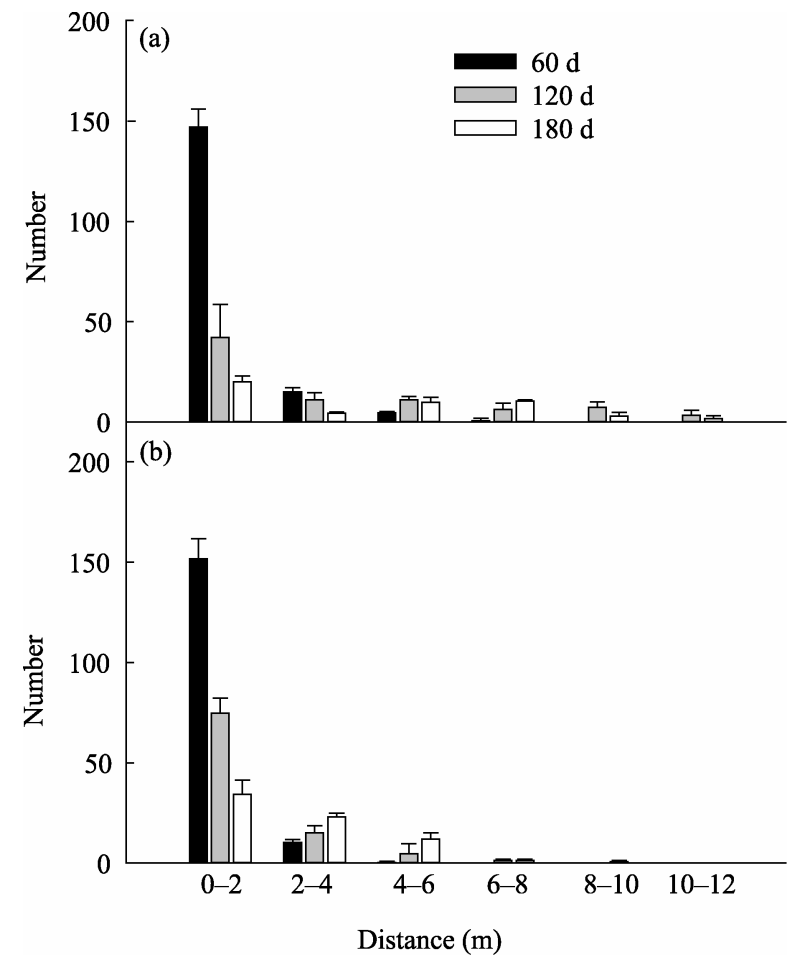

Fig. 4 Numbers of the paper pieces recovered and the distance of retrieval at three time intervals at SD (a) and SSD (b) plots. Distance $(m)$ from the origin was measured. Bars represent Means \pm SD $(n=3)$.

total litter biomass. The $\mathrm{P}$ loss in the same plots was 7.4, 46.9, and $69.8 \mathrm{mg} \mathrm{P} / \mathrm{m}^{2}$, about $56.4 \%, 49.6 \%$, and $44.6 \%$, respectively, of the total $\mathrm{P}$. The returned $\mathrm{P}$ amount for $\mathrm{AD}, \mathrm{SSD}$, and SD was 5.5, 47.6, and 131.8 $\mathrm{mg} \mathrm{P} / \mathrm{m}^{2}$, about $43.6 \%, 50.4 \%$, and $65.4 \%$, respectively of the total P (Table 5).

\subsection{Relationship between both the loss and return of litter $P$ and total litter $P$}

Significant linear regression was observed between both the loss and return of litter $\mathrm{P}$ and total litter $\mathrm{P}$ for AD, SSD, and SD $(P<0.01$, Fig. 5). The sum of the slopes of the two regression lines was equal to 1 , and these slopes represented the rates of loss and return of litter P. The loss and return rates of litter $\mathrm{P}$ were significantly different among $\mathrm{AD}, \mathrm{SSD}$, and $\mathrm{SD}$
$(P<0.01)$. The trend of loss rate was declining and that of return rate was increasing from $\mathrm{AD}$ to $\mathrm{SD}$.

The intersection point of the two regression lines was the threshold at which the amounts of loss and return of litter $\mathrm{P}$ were equal. No intersection point was observed for $\mathrm{AD}$, since the amount of total litter $\mathrm{P}$ was more than $0 \mathrm{mg} \mathrm{P} / \mathrm{m}^{2}$. The loss rate of litter $\mathrm{P}$ (0.52) was higher than the return rate of litter $\mathrm{P}$ (0.48), resulting in a higher amount of litter P loss than that of litter $\mathrm{P}$ return. The return rates of litter $\mathrm{P}$ were higher than the loss rates $(0.32$ and 0.17 , respectively) for SSD and SD (0.67 and 0.83 , respectively). The intersections of the regression lines were the two points of $T_{1}\left(85.5 \mathrm{mg} \mathrm{P} / \mathrm{m}^{2}, 42.8 \mathrm{mg} \mathrm{P} / \mathrm{m}^{2}\right)$ for SSD and $T_{2}\left(110.6 \mathrm{mg} \mathrm{P} / \mathrm{m}^{2}, 55.3 \mathrm{mg} \mathrm{P} / \mathrm{m}^{2}\right)$ for $\mathrm{SD}$. If the amount of total $\mathrm{P}$ was lower than $85.5 \mathrm{mg}$ $\mathrm{P} / \mathrm{m}^{2}$ in SSD and $110.6 \mathrm{mg} \mathrm{P} / \mathrm{m}^{2}$ in SD, the amount of $\mathrm{P}$ loss was higher than that of $\mathrm{P}$ return, and vice versa.

\section{Discussion}

\subsection{The loss and return of litter $P$ for different ty- pes of sand dunes}

The loss and return of litter $\mathrm{P}$ varied across different sand dune systems because of precipitation, vegetation biomass, strong gales during the windy season ( $\mathrm{Hu}$ et al., 2009) and the decomposition rate of plant litter (Kemp et al., 2003). Precipitation determines soil water content, which primarily limits vegetation biomass in sandy land. Modifications in the cover and biomass of herbs and shrubs occur because of competition for soil water (Li et al., 2004; Lyne Ensign et al., 2006). Many plants with low leaf biomass and, thus, decreased evapotranspiration, can survive in these areas (Singh, 2004) and reduce the litter biomass (Li et al., 2004).

The vegetation biomass varied across different sand dune systems. Strong wind erosion and sand burial (Yan et al., 2005) and low soil fertility (Su et al., 2005) lead

Table 5 Returned litter biomass and P amount in the three types of sand dunes

\begin{tabular}{|c|c|c|c|c|}
\hline & Total litter $\left(\mathrm{g} / \mathrm{m}^{2}\right)$ & Returned litter $\left(\mathrm{g} / \mathrm{m}^{2}\right)$ & Total P $\left(\mathrm{mg} \mathrm{P} / \mathrm{m}^{2}\right)$ & Returned $\mathrm{P}\left(\mathrm{mg} \mathrm{P} / \mathrm{m}^{2}\right)$ \\
\hline $\mathrm{AD}$ & $14.4 \pm 24.7^{c}$ & $7.8 \pm 13.8^{\mathrm{c}}$ & $12.6 \pm 20.6^{c}$ & $5.5 \pm 10.1^{\mathrm{c}}$ \\
\hline SSD & $78.3 \pm 16.9^{b}$ & $43.8 \pm 5.1^{\mathrm{b}}$ & $94.5 \pm 27.1^{\mathrm{b}}$ & $47.6 \pm 14.7^{\mathrm{b}}$ \\
\hline SD & $186.5 \pm 60.5^{\mathrm{a}}$ & $131.2 \pm 42.7^{\mathrm{a}}$ & $201.6 \pm 72.6^{\mathrm{a}}$ & $131.8 \pm 58.7^{\mathrm{a}}$ \\
\hline$P$ value & $<0.001$ & $<0.001$ & $<0.001$ & $<0.001$ \\
\hline
\end{tabular}




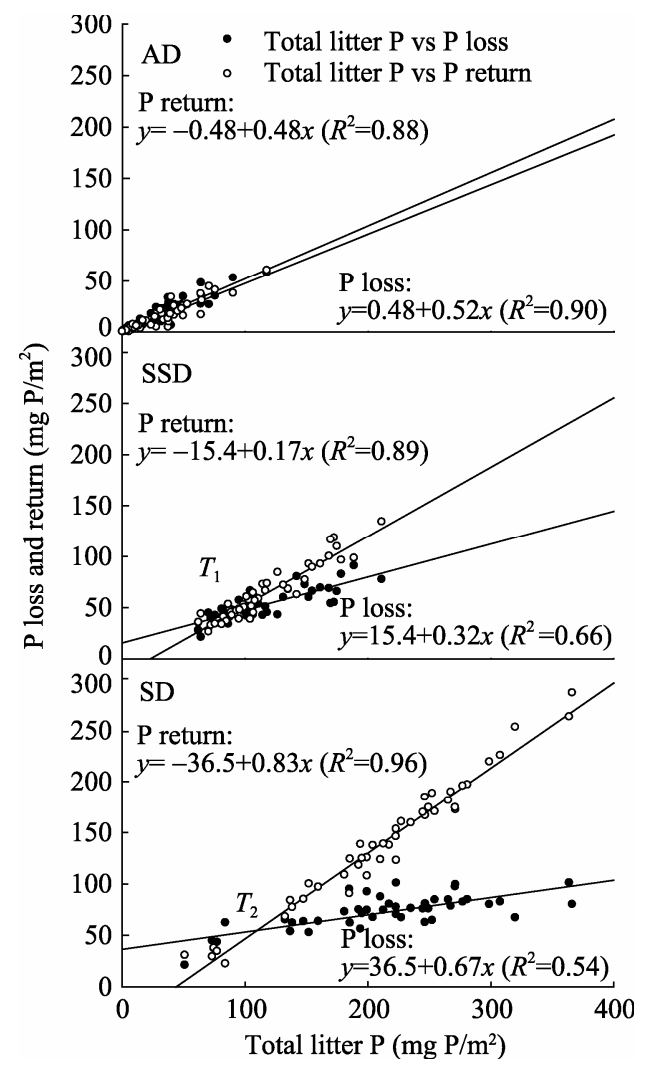

Fig. 5 Relationship between both the loss and return of litter $P$ and total litter $P$ for $A D, S S D$ and SD.

to significant variations in vegetation biomass ( $\mathrm{Su}$ and Zhao, 2003; Zuo et al., 2009a) and lower vegetation biomass (Zhang et al., 2004) in AD. The vegetation biomass in SSD was higher than that in AD because of the better soil structure and larger seed bank and vegetation cover (Liu et al., 2007). However, sand activity during the windy season and livestock grazing during the growing season reduce vegetation biomass (Li et al., 2008). While the vegetation biomass in SD was the highest among the three types of sand dunes (Su and Zhao, 2003; Su et al., 2004; Zhao et al., 2008), the higher spatial variability of soil nutrients after the establishment of shrubs shifted SD toward a smaller vegetation biomass (Ridolfi et al., 2008; Dong et al., 2009).

Strong wind is the main reason for litter P loss in sand dunes during the windy season. Gales are powerful and frequent in the Horqin Sandy Land during the windy season (Wang et al., 2005). Vegetation influences surface roughness length and wind resistance on sand dunes (Bressolier and Thomas, 1977). Leaf litter is moved leeward by strong gales and blown away from sand dune communities with low vegetation cover toward dune slacks or other systems with high vegetation cover and low wind speed.

$P$ in plant litter is released to top soil by decomposition (Moretto et al., 2001; Regina, 2001; Costa et al., 2004; Mubarak et al., 2008). Decomposition of plant litter leads to $\mathrm{P}$ accumulation from deeper soil layers to the soil surface and promotes the reuse of $\mathrm{P}$ by plants (Yang et al., 2004; Soares et al., 2008). A lower plant-litter decomposition rate decreases $\mathrm{P}$ return, particularly in sand dunes. Plant material, soil, and air moisture are the main factors that influence plant-litter decomposition rates (Koukoura et al., 2003), and the decomposition rate of litter buried in soil is higher than when on the soil surface in arid areas (Martinez-Yrizar et al., 2007; Mubarak et al., 2008). Placing litter on soil surface to measure the decomposition rate in sand dune systems thus provides simulation much closer to the actual circumstances. More than $50 \%$ of the litter mass and $\mathrm{P}$ content has been reported to remain after 2 years when litter is placed on the soil surface (Moretto et al., 2001; Kemp et al., 2003).

\subsection{Relationship between both the loss and return of litter $\mathbf{P}$ and total litter $\mathbf{P}$}

The loss and return of litter $\mathrm{P}$ in the sandy soil of arid and semi-arid areas is strongly influenced by vegetation restoration. Vegetation restoration is characterized by the increase of plant biomass, that is, the increase in litter biomass and the amount of litter P. AD, SSD, and SD can be identified as the three stages of vegetation restoration. Plant species diversity, vegetation cover, and vegetation biomass increased during a restoration experiment conducted previously ( $\mathrm{Su}$ et al., 2005; Zhao et al., 2007; Zuo et al., 2009b). Thus, increasing vegetation biomass reduces wind disturbance on sand dune systems (Bressolier and Thomas, 1977; Liu et al., 2005; Zhao et al., 2006), leading to a decreased $\mathrm{P}$ loss rate and increased $\mathrm{P}$ return rate. The amount and rate of litter P loss could decrease further if wind resistance ability is increased by increasing vegetation biomass and litters remaining on the soil surface with decreasing grazing and trampling of animals. Consequently, the amount of returned litter $\mathrm{P}$ could be improved. 
The loss and return of litter $\mathrm{P}$ in sandy soil is important for vegetation restoration in this area. $\mathrm{P}$ released by litter decomposition enters the soil and increases soil fertility under the plant canopy. P can be used by plants to increase vegetation biomass. If the loss of litter P increases, the return of litter P decreases, accelerating the loss of soil $\mathrm{P}$, which is not conducive to vegetation restoration. Conversely, the increased return of litter $\mathrm{P}$ facilitates vegetation restoration.

\section{Conclusions}

In sand dune ecosystems, low vegetation biomass leads to low total litter $\mathrm{P}$ given the characteristics of soil and climate in such environments. Significant litter loss occurs in different sand dune types, leading to

\section{References}

Berg B, Mcclaugherty C. 1989. Nitrogen and phosphorus release from decomposing litter in relation to the disappearance of lignin. Canadian Journal of Botany, 67: 1148-1156.

Berg B. 2000. Litter decomposition and organic matter turnover in northern forest soils. Forest Ecology and Management, 133: 13-22.

Bonanomi G, Caporaso S, Allegrezza M. 2006. Short-term effects of nitrogen enrichment, litter removal and cutting on a Mediterranean grassland. Acta Oecologica, 30: 419-425.

Bremner J. 1996. Nitrogen-Total, Methods of Soil Analysis, Part 3. Chemical Methods. Madison: Soil Science of America and American Society of Agronomy, 1085-1122.

Bressolier C, Thomas Y. 1977. Studies on wind and plant interactions on French Atlantic coastal dunes. Journal of Sedimentary Petrology, 47: $331-338$.

Chen Y X, Zhu G W, Tian G M, et al. 2003. Phosphorus and copper leaching from dredged sediment applied on a sandy loam soil: column study. Chemosphere, 53: 1179-1187.

Cole C, Innis G, Stewart J. 1977. Simulation of phosphorus cycling in semiarid grasslands. Ecology, 58: 2-15.

Costa G S, Franco A A, Damasceno R N, et al. 2004. Nutrient input through litter in a degraded area revegetated with legume trees. Revista Brasileira de Ciencia do Solo, 28: 919-927.

Dong X W, Zhang X K, Bao X L, et al. 2009. Spatial distribution of soil nutrients after the establishment of sand-fixing shrubs on sand dune. Plant, Soil and Environment, 55: 288-294.

Filippelli G M. 2008. The global phosphorus cycle: past, present, and future. Elements, 4: 89-95.

He Y Q, Zhu Y G, Smith S E, et al. 2002. Interactions between soil moisture content and phosphorus supply in spring wheat plants grown in pot culture. Journal of Plant Nutrition, 25: 913-925.

Hu X, Liu L Y, Li S J, et al. 2009. Estimation of sand transportation rate litter P loss from the sand dune system. Increasing the vegetation biomass can increase the litter $\mathrm{P}$ return rate, thus decreasing litter $\mathrm{P}$ loss rate. Litter $\mathrm{P}$ return has a positive effect on vegetation restoration, whereas litter P loss yields negative effects on sand dune systems. Therefore, promoting vegetation restoration is necessary to improve the stability of sand dune ecosystems.

\section{Acknowledgements}

This work was financially supported by the National Natural Science Foundation of China (30800163). We thank CaiYan LU, XiaoHua XUE, and Ming LI for their help during the investigation and laboratory experiments. We thank Professor ChengYou $\mathrm{CAO}$ for helping with the manuscript revision and polishing.

for fixed and semi-fixed dunes using meteorological wind data. Pedosphere, 19: 129-136.

Jaramillo-Botero C, Santos R H S, Fardim M P, et al. 2008. Litter production and potential nutrient of native tree species in an agroforestry system at Zona da Mata, MG, Brazil. Revista Arvore, 32: 869-877.

Kemp P R, Reynolds J F, Virginia R A, et al. 2003. Decomposition of leaf and root litter of Chihuahuan Desert shrubs: effects of three years of summer drought. Journal of Arid Environments, 53: 21-39.

Koukoura Z, Mamolos A P, Kalburtji K L. 2003. Decomposition of dominant plant species litter in a semi-arid grassland. Applied Soil Ecology, 23: 13-23.

Li F R, Kang L F, Zhang H, et al. 2005. Changes in intensity of wind erosion at different stages of degradation development in grasslands of Inner Mongolia, China. Journal of Arid Environments, 62: $567-585$.

Li F R, Zhao W Z, Liu J L, et al. 2009. Degraded vegetation and wind erosion influence soil carbon, nitrogen and phosphorus accumulation in sandy grasslands. Plant and Soil, 317: 79-92.

Li X R, Ma F Y, Xiao H L, et al. 2004. Long-term effects of revegetation on soil water content of sand dunes in arid region of Northern China. Journal of Arid Environments, 57: 1-16.

Li Y Q, Zhao H L, Zhao X Y, et al. 2008. Effects of desertification process on plant-soil carbon and nitrogen pools in the semiarid Horqin Sandy Land. Proceedings of Information Technology and Environmental System Sciences: ITESS, 4: 454-457.

Liu L Y, Skidmore E, Hasi E, et al. 2005. Dune sand transport as influenced by wind directions, speed and frequencies in the Ordos Plateau, China. Geomorphology, 67: 283-297.

Liu S L, Wang T, Chen G T, et al. 2008. Field investigation of surface sand and dust movement over different sandy grasslands in the 
Otindag Sandy Land, China. Environmental Geology, 53: $1225-1233$.

Liu Z, Yan Q, Liu B, et al. 2007. Persistent soil seed bank in Agriophyllum squarrosum (Chenopodiaceae) in a deep sand profile: variation along a transect of an active sand dune. Journal of Arid Environments, 71: 236-242.

Lyne Ensign K, Webb E A, Longstaffe F J. 2006. Microenvironmental and seasonal variations in soil water content of the unsaturated zone of a sand dune system at Pinery Provincial Park, Ontario, Canada. Geoderma, 136: 788-802.

Martinez-Yrizar A, Nunez S, Burquez A. 2007. Leaf litter decomposition in a southern Sonoran Desert ecosystem, northwestern Mexico: effects of habitat and litter quality. Acta Oecologica, 32: 291-300.

Meier I C, Leuschner C, Hertel D. 2005. Nutrient return with leaf litter fall in Fagus sylvatica forests across a soil fertility gradient. Plant Ecology, 177: 99-112.

Moretto A S, Distel R A, Didoné N G. 2001. Decomposition and nutrient dynamic of leaf litter and roots from palatable and unpalatable grasses in a semi-arid grassland. Applied Soil Ecology, 18: 31-37.

Mubarak A R, Elbashir A A, Elamin L A, et al. 2008. Decomposition and nutrient release from litter fall in the semi-arid tropics of Sudan. Communications in Soil Science and Plant Analysis, 39: 2359-2377.

Njoukam R, Oliver R, Peltier R. 1999. Nutrient return to soil through litter fall in Pinus kesiya Royle ex. Gordon plantations in West Cameroon. Annals of Forest Science, 56: 431-439.

Okin G, Mahowald N, Chadwick O, et al. 2004. Impact of desert dust on the biogeochemistry of phosphorus in terrestrial ecosystems. Global Biogeochemical Cycles, 18, doi:10.1029/2003GB002145.

Osono T, Takeda H. 2004. Accumulation and release of nitrogen and phosphorus in relation to lignin decomposition in leaf litter of 14 tree species. Ecological Research, 19: 593-602.

Regina I S. 2001. Litter fall, decomposition and nutrient release in three semi-arid forests of the Duero Basin, Spain. Forestry, 74: 347-358.

Ridolfi L, Laio F, D'odorico P. 2008. Fertility island formation and evolution in dryland ecosystems. Ecology and Society, 13: 5.

Silveira N D, Pereira M G, Polidoro J C, et al. 2007. Nutrient deposition by litter in agroforestry systems in Paraty (RJ). Ciencia Florestal, 17: 129-136.

Singh G. 2004. Influence of soil moisture and nutrient gradient on growth and biomass production of Calligonum polygonoides in Indian desert affected by surface vegetation. Journal of Arid Environments, 56: 541-558.

Smith F W. 2002. The phosphate uptake mechanism. Plant and Soil, 245: 105-114.

Soares I, Queiroz J D, De Oliveira V H, et al. 2008. Litter production and nutrient cycles in the young dwarf cashew culture. Revista
Arvore, 32: 173-181.

Su Y Z, Zhao H F. 2003. Soil properties and plant species in an age sequence of Caragana microphylla plantations in the Horqin Sandy Land, North China. Ecological Engineering, 20: 223-235.

Su Y Z, Zhao H L, Li Y L, et al. 2004. Influencing mechanisms of several shrubs on soil chemical properties in semiarid Horqin Sandy Land, China. Arid Land Research and Management, 18: 251-263.

Su Y Z, Zhang T H, Li Y L, et al. 2005. Changes in soil properties after establishment of Artemisia halodendron and Caragana microphylla on shifting sand dunes in semiarid Horqin Sandy Land, Northern China. Environmental Management, 36: 272-281.

Wang X, Dong Z, Yan P, et al. 2005. Wind energy environments and dunefield activity in the Chinese deserts. Geomorphology, 65: 33-48.

Yan Q L, Liu Z M, Zhu J J, et al. 2005. Structure, pattern and mechanisms of formation of seed banks in sand dune systems in northeastern Inner Mongolia, China. Plant and Soil, 277: 175-184.

Yang Y S, Guo J F, Chen G S, et al. 2004. Litterfall, nutrient return, and leaf-litter decomposition in four plantations compared with a natural forest in subtropical China. Annals of Forest Science, 61: 465-476.

Zhang T H, Zhao H L, Li S G, et al. 2004. A comparison of different measures for stabilizing moving sand dunes in the Horqin Sandy Land of Inner Mongolia, China. Journal of Arid Environments, 58: 203-214.

Zhao H L, Yi X Y, Zhou R L, et al. 2006. Wind erosion and sand accumulation effects on soil properties in Horqin Sandy Farmland, Inner Mongolia. Catena, 65: 71-79.

Zhao H L, Zhou R L, Su Y Z, et al. 2007. Shrub facilitation of desert land restoration in the Horqin Sandy Land of Inner Mongolia. Ecological Engineering, 31: 1-8.

Zhao Q, Zeng D H, Fan Z P, et al. 2008. Effect of land cover change on soil phosphorus fractions in southeastern Horqin Sandy Land, Northern China. Pedosphere, 18: 741-748.

Zuo X A, Zhao X Y, Zhao H L, et al. 2008. Spatial pattern and variability of vegetation in degradation processes of sandy grassland in Horqin Sandy Land. In: Li G, Jia Z, Fu Z. Proceedings of Information Technology and Environmental System Sciences: ITESS 2008, Vol 1. Beijing: Publishing House of Electronics Industry, 662-667.

Zuo X A, Zhao H L, Zhao X Y, et al. 2009a. Vegetation pattern variation, soil degradation and their relationship along a grassland desertification gradient in Horqin Sandy Land, Northern China. Environmental Geology, 58: 1227-1237.

Zuo X A, Zhao X Y, Zhao H L, et al. 2009b. Spatial heterogeneity of soil properties and vegetation-soil relationships following vegetation restoration of mobile dunes in Horqin Sandy Land, Northern China. Plant and Soil, 318: 153-167. 